\title{
Fermentation Characteristics and Nitrogen Retention of Madura Cattle Fed Complete Rations Containing Soybean Pod and By-Products
}

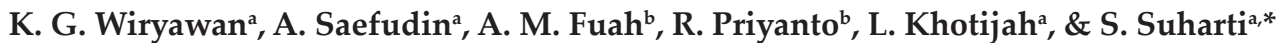 \\ a Department of Nutrition and Feed Technology, Faculty of Animal Science, Bogor Agricultural University, Indonesia \\ ${ }^{b}$ Department of Animal Production Technology, Faculty of Animal Science, Bogor Agricultural University, Indonesia \\ Jalan Agatis Kampus Fapet IPB Darmaga, Bogor, West Java, Indonesia 16680 \\ (Received 23-11-2016; Reviewed 09-01-2017; Accepted 24-02-2017)
}

\begin{abstract}
This study was aimed to evaluate the effect of complete rations containing soybean pod and soybean by-products (soybean meal and tofu waste) on rumen microbial population, fermentation characteristics, nutrient digestibility, and nitrogen retention of Madura cattle. Twelve Madura cattle of 1.5 years of age were given 4 feeding treatments in triplicates in randomized block design experiment. The treatments included T0 $(\mathbf{1 0 0} \%$ native grass) as a negative control, T1 (concentrate: grass $(60: 40)$ as a positive control, T2 (complete ration containing $15 \%$ soybean pods), and T3 (complete ration containing $30 \%$ soybean pods). The treatments were based on feeding practices commonly applied by farmers in the village. The results showed that the use of concentrate rations or complete rations containing soybean pod and by-product did not affect protozoa population, ammonia concentration, and total VFA production compared to cattle fed $100 \%$ native grass. In contrast, the use of concentrate rations or complete rations containing soybean pod and by-products reduced acetate and increased butyrate proportion compared to native grass. The use of a concentrate ration resulted the highest propionate proportion. Methane estimation increased with the use of concentrate ration or complete ration containing $15 \%$ soybean pod, but it decreased when the level of soybean pod was increased to $30 \%$. It can be concluded that soybean pod has a potential to be used as a fiber source in beef cattle ration to substitute native grass.
\end{abstract}

Keywords: rumen fermentation, nutrient digestibility, nitrogen retention, madura cattle, soybean pod

\section{ABSTRAK}

Penelitian ini bertujuan untuk mengkaji pengaruh ransum komplit yang mengandung kulit polong kedelai dan hasil ikutan kedelai (bungkil kedelai dan ampas tahu) pada populasi mikrob rumen, karakteristik fermentasi, kecernaan nutrien, dan retensi nitrogen. Penelitian menggunakan 12 ekor sapi Madura umur 1,5 tahun. Rancangan yang digunakan adalah rancangan acak kelompok dengan 4 perlakuan pakan dan setiap perlakuan terdiri atas 3 kelompok sebagai ulangan. Perlakuan yang digunakan adalah T0 (100\% rumput lapang)/kontrol negatif, T1 (konsentrat:hijauan= 60:40)/ kontrol positif, T2 (ransum komplit yang mengandung kulit polong kedelai 15\%), dan T3 (ransum komplit yang mengandung kulit polong kedelai 30\%). Perlakuan yang digunakan berbasis pada pakan yang biasa digunakan oleh rakyat peternak. Hasil penelitian menunjukkan bahwa ransum komplit yang mengandung ikutan kedelai serta kulit polong kedelai 15\% dan $30 \%$ tidak mempengaruhi populasi protozoa, konsentrasi amonia, dan produksi VFA total dibandingkan dengan ransum yang $100 \%$ rumput lapang. Sebaliknya, penggunaan ransum konsentrat atau ransum komplit yang mengandung kulit polong kedelai dan hasil ikutan kedelai mampu menurunkan proporsi asetat dan meningkatkan proporsi butirat dibandingkan dengan ternak yang mendapat rumput lapang saja. Penggunaan ransum konsentrat menghasilkan proporsi propionat yang paling tinggi. Estimasi metan meningkat dengan penggunaan ransum konsentrat atau ransum komplit yang mengandung kulit polong kedelai $15 \%$, namun menurun pada level kulit polong kedelai 30\%. Dapat disimpulkan bahwa kulit polong kedelai sangat berpotensi dan dapat digunakan sebagai sumber serat pengganti rumput pada ternak sapi pedaging.

Kata kunci: Fermentasi rumen, kecernaan nutrien, retensi nitrogen, sapi madura, kulit polong kedelai

${ }^{*}$ Corresponding author:

E-mail: harti_ss@yahoo.com; sri_suharti@ipb.ac.id 


\section{INTRODUCTION}

Beef cattle is one of the potent livestock in Indonesia which needs to be improved both in numbers and productivity to meet the increasing meat demand. The main problem behind the low productivity of beef cattle raised by farmers in the villages would be the insufficiency of feed resources including the low quality of feed nutrients available for the animal, especially the deficiency of protein/nitrogen and low feed intake. There are some strategies required to improve the productivity of beef cattle such as the provision of sufficient feed stuffs as the main sources of protein. The potential feed stuffs as sources of protein are soybean meals and soybean wastes. Soybean meal (SBM) is the remained material after the extraction of oil from SB flakes, with about $48 \%$ crude protein (CP) content (Mukherjee et al., 2016).

Nowadays, around $70 \%$ of the domestic requirement of soybean meal as an animal feed was fulfilled by import. However, Indonesia has very large and potential land areas available for production of soybean to meet the demand of the human population as well as livestock. Soybean may adapt to a variety of land types including marginal land by using applied technology for improvement of land quality. In 2015, the harvested area of soybean in Indonesia reached 613885 Ha with soybean production of around 963099 tons and the proportion of soybean pod was around $45 \%$ from the whole soybean production (BPS, 2015).

Integration between beef cattle and soybean farmings may become one of the alternative solutions to increase beef cattle production through improvement of feed efficiency. Several studies have been carried out to evaluate the use of soybean meal as feed resources to improve beef cattle production. Kennedy (2012) reported that the use of $15 \%$ soybean meal in sheep ration combined with corn cob increased average daily gain. Moreover, Foster et al. (2014) suggested that there were enhancements of DM, OM, and $\mathrm{N}$ intakes, $\mathrm{N}$ digestibility and retention, and concentrations of rumen metabolites in sheep supplemented with soybean meal, perennial peanut, annual peanut, and cowpea peanut. Moreover, the concentrations of $\mathrm{NH}_{3}-\mathrm{N}$ and PUN in the rumen also increased when the animals were supplemented with bahiagrass haylage. Supplementation of soybean meal also increased the digestibility of dry matter compared to control diet and yielded the highest $\mathrm{N}$ intake, digestibility, and retention.

This research was aimed to evaluate the effect of complete feed containing soybean byproducts on rumen microbial population, fermentation characteristic, and production performance of Madura cattle.

\section{MATERIALS AND METHODS}

\section{Experimental Design and Preparation}

Twelve Madura beef cattle of 1.5 years of age with an average initial body weight of $175.64 \pm 16.4 \mathrm{~kg}$ were assigned into 4 feeding treatments with 3 animals per treatment. The treatments were T0 (100\% native grass) as a negative control, T1 (concentrate: grass (60:40) as a positive control, T2 (complete ration containing 15\% soybean pods), and T3 (complete ration containing 30\% soybean pods). The treatments were based on feeding practices commonly applied by farmers in the village.

Before starting the experiment, preparation was made on feed and drinking facilities, beef cattle, and fodder. The twelve local cattle were obtained by collaboration with small holding farmers around the IPB campus and individually kept in the experimental units for 2 weeks of adaptation period and 90 days for feeding treatments. The local cattle were weighed to obtained initial liveweight, then grouped based on initial liveweight in order to minimize animal variations among treatments.

\section{Animal Diet}

The rations were formulated from forage (grass) and soybean waste. Soybean wastes were obtained from farmers at Grobogan, Central Java. As a positive control, there were three cattle fed by concentrate ration consisting of cassava waste, pollard, soybean meal, molasses (tetes), $\mathrm{CACO}_{3}$, urea, and premix. These feedstuffs were formulated to fulfill nutrient requirements of the experimental cattle as suggested by Kearl (1982), which contained $14 \%$ crude protein and $68-70 \%$ total digestible nutrient (TDN). The nutrient composition of soybean pods was presented in Table 1 and ration formulations for all treatments were presented in Table 2.

\section{Sampling and Measurement}

Rumen fluid was collected after 80 days of treatment and obtained by using stomach tube at $4 \mathrm{~h}$ after morning feeding. The rumen fluid was screened through a double layer of cheesecloth and the supernatant yielded was kept for bacteria and protozoa enumeration.

The numbers of protozoa in the rumen fluid were counted under a microscope according to Ogimoto \& Imai (1981). The $0.5 \mathrm{~mL}$ rumen fluid was mixed with 0.5 mL Trypan Blue Formalin Saline (TBFS) which consisted of $100 \mathrm{~mL}$ formaldehide $35 \%, 2$ g trypan blue, 8

Table 1. Nutrient composition of soybean pod (dry matter basis)

\begin{tabular}{lr}
\hline Nutrient & $(\%)$ \\
\hline Dry matter & \\
Ash & \\
Ether extract $^{1}$ & 93.7 \\
Crude protein $^{1}$ & 5.1 \\
Crude fiber $^{1}$ & 2.5 \\
Nitrogen free extract $^{1}$ & 5.5 \\
Hemicellulose $^{2}$ & 35.4 \\
Cellulose $^{2}$ & 51.5 \\
Lignin $^{2}$ & 19.4 \\
\hline
\end{tabular}

Note: ${ }^{1}$ Analyzed by Pusat Penelitian Sumberdaya Hayati dan Bioteknologi, Bogor Agricultural University, Indonesia; ${ }^{2}$ Analyzed by Livestock Research Centre, Ciawi, Bogor, West Java, Indonesia. 
Table 2. Ration formulation of all feeding treatments

\begin{tabular}{|c|c|c|c|c|}
\hline & \multicolumn{4}{|c|}{ Treatments } \\
\hline & T0 & $\mathrm{T} 1$ & $\mathrm{~T} 2$ & T3 \\
\hline \multicolumn{5}{|l|}{ Ingredient $(\%)$} \\
\hline Native grass & 100.0 & 40.0 & - & - \\
\hline Cassava waste meal & - & 21.0 & 20.0 & 14.0 \\
\hline Pollard & - & 18.0 & 17.0 & 18.0 \\
\hline Soybean meal & - & 8.5 & 5.0 & 10.0 \\
\hline Coconut cake meal & - & 5.0 & 0.0 & 0.0 \\
\hline Molasses & - & 5.0 & 15.0 & 15.0 \\
\hline $\mathrm{CaCO}_{3}$ & - & 1.0 & 1.5 & 1.5 \\
\hline Urea & - & 1.0 & 1.0 & 1.0 \\
\hline Premix & - & 0.5 & 0.5 & 0.5 \\
\hline Tofu waste & - & - & 25.0 & 10.0 \\
\hline Soybean pod & - & - & 15.0 & 30.0 \\
\hline \multicolumn{5}{|l|}{ Nutrient composition (\%) } \\
\hline Dry matter (DM) & 17.6 & 59.1 & 67.1 & 80.1 \\
\hline Ash & 12.0 & 7.8 & 5.0 & 5.5 \\
\hline Crude protein $(\mathrm{CP})$ & 9.8 & 15.3 & 15.2 & 15.0 \\
\hline Ether extract (EE) & 1.1 & 3.8 & 2.9 & 3.9 \\
\hline Crude fiber $(\mathrm{CF})$ & 31.9 & 19.2 & 17.1 & 19.4 \\
\hline Nitrogen free extract (NFE) & 45.2 & 54.3 & 59.6 & 56.1 \\
\hline Total digestible nutrient (TDN)* & 48.4 & 68.5 & 68.3 & 68.2 \\
\hline Lignin* & 10.0 & 11.4 & 7.5 & 8.0 \\
\hline
\end{tabular}

Note: $\mathrm{T} 0=100 \%$ native grass), $\mathrm{T} 2=$ concentrate $:$ grass $(60: 40), \mathrm{T} 3=\mathrm{com}-$ plete feed containing $15 \%$ soybean pods, T4= complete feed containing $30 \%$ soybean pods. ${ }^{*}$ by calculation.

$\mathrm{g} \mathrm{NaCl}$, and $900 \mathrm{~mL}$ distilled water and diluted 5 times. The population of protozoa was counted directly on 5 divisions by using a counting chamber $\left(0.1 \mathrm{mmx} 1 \mathrm{~mm}^{2}\right)$ under a microscope (40x) and calculated by the following formula: $\mathrm{P}=(\mathrm{n} / 5) \times 10^{4} \times \mathrm{d}$, where $\mathrm{P}=$ the number of ciliates per $1 \mathrm{~mL}$ rumen contents, $\mathrm{n}=$ the number of division that counted in the counting chamber, $d=$ multiple dilutions of the sample.

Population of total bacteria were counted according to Ogimoto \& Imai (1981) by using roller tube method and Rumen-Fluid Glucose Cellobiose Agar (RGCA) Modification. The RGCA solution consisted of $15 \mathrm{~mL}$ mineral solution I, $15 \mathrm{~mL}$ mineral solution II, $0.1 \mathrm{~mL}$ Resazurin $0.1 \%$ solution, $40 \mathrm{~mL}$ distilled water, $2 \mathrm{~g}$ bacto agar, $30 \mathrm{ml}$ rumen fluid, $0.2 \mathrm{~g}$ glucose, $0.2 \mathrm{~g}$ cellobiose, $0.1 \mathrm{~g}$ cysteine. $\mathrm{HCl} . \mathrm{H}_{2} \mathrm{O}, 1 \mathrm{~mL} \mathrm{Na} \mathrm{CO}_{3} 8 \%$ solution, $1 \mathrm{~g}$ bacto casiton, $0.3 \mathrm{~g}$ yeast extract, $0.2 \mathrm{~g}$ yeast extract, $0.2 \mathrm{~g}$ soluble starch, $0.4 \mathrm{~g} \mathrm{NaHCO}_{3^{\prime}}$ and $1 \mathrm{~mL}$ sodium lactate. Forty-five $\mathrm{mL}$ of anaerobic dilution solution and 0.5 $\mathrm{mL}$ of rumen sample were placed in the hungate tube. The samples were diluted until 10 times dilution. The $0.5 \mathrm{~mL}$ samples from dilutions 6 to 10 were placed into petri dish that contained RGCA media, then rotated to form a figure of eight in order to mix the sample homogeneously. The samples were incubated for 48 hours at a temperature of $37-40^{\circ} \mathrm{C}$. The calculation of the bacteria population was conducted by using the following formula: $\mathrm{BP}=\mathrm{C} \times 10^{\mathrm{n}} \times 2$, where $\mathrm{BP}=$ bacteria population, $\mathrm{C}=$ the number of colony forming unit, $\mathrm{n}=$ the number of dilution.

Ammonia (N-NH3) concentrations were measured by using the micro diffusion method (Conway, 1962).
Analysis of total and proportional VFA concentrations were conducted by using gas chromatography (Chrompack CP9002, Netherlands, flame ionized detector, Capillary column type WCOT Fused Silica $25 \mathrm{~m} \mathrm{x}$ $0.32 \mathrm{~mm}$, oven temperature: conditioning at $60^{\circ} \mathrm{C}$ and running at $115^{\circ} \mathrm{C}$ and nitrogen as gas carrier). The $\mathrm{pH}$ of supernatant of rumen aliquot obtained from the screening was adjusted to 3-4 by adding $\mathrm{H}_{2} \mathrm{SO}_{4}$. Before being injected to the GC machine, the $1.5 \mathrm{~mL}$ rumen supernatant was mixed with $30 \mathrm{mg}$ sulfosalicylic acid $\left(\mathrm{C}_{7} \mathrm{H}_{6} \mathrm{O}_{6} \mathrm{~S} .2 \mathrm{H}_{2} \mathrm{O}\right)$ and centrifuged with refrigerated centrifuge $\left(7^{\circ} \mathrm{C}\right)$ at $12,000 \mathrm{rpm}$ for $10 \mathrm{~min}$. Thus, the solution was injected to the GC around $0.5 \mu \mathrm{L}$ (Suharti et al., 2011). Methane estimation was calculated from the molar proportion of VFA according to Moss et al. (2000) by using the formula: $0.45(\mathrm{C} 2)-0.275(\mathrm{C} 3)+0.4(\mathrm{C} 4)$ where $\mathrm{C} 2=$ acetate, $\mathrm{C} 3=$ propionate, and $\mathrm{C} 4=$ butyrate.

Collection of total feces during 7 concecutive days at the end of the treatments was conducted to measure the nutrient digestibility. About $10 \%(w / w)$ of total feces was sampled from each cattle and dried at $60^{\circ} \mathrm{C}$ in the oven for proximate analysis preparation (dry matter (DM), organic matter (OM), crude fiber (CF), crude protein $(\mathrm{CP})$, and ether extract (EE)). The percentage digestibility of DM (\%) was calculated according to the formula DM $(\%)=((\mathrm{DM}$ Intake - fecal DM $) / D M$ intake $))$ x 100\%. Other nutrient digestibilities (OM, CF, CP, and EE) were quantified by using the same equation. Total production of urine was collected during 7 consecutive days simultaneously with the total fecal collection and nitrogen concentration in the urine was analyzed to measure nitrogen retention (Fuah et al., 2016).

\section{Data Analysis}

Statistical analysis of the data was carried out by ANOVA using General Linear Model Procedure (SPSS Version 13.0 for Windows). If there were any differences in response variables, differences between groups were tested using Duncan's multiple range test.

\section{RESULTS}

\section{Nutrient Intake and Digestibility}

The use of soybean pod at the level of $15 \%$ in the complete feed (T2) significantly increased $(\mathrm{P}<0.05)$ dry matter and crude protein intakes compared to the other treatments. In contrast, the use of soybean pod at the level of $30 \%$ in the complete feed (T3) slightly decreased dry matter and crude protein intakes compared to the lower level of soybean pod. Furthermore, the use of soybean pod at the level of $30 \%$ in the complete feed (T3) significantly increased $(\mathrm{P}<0.05)$ ether extract intake compared to the other treatments. The use of native grass based ration $(\mathrm{T} 0)$ significantly increased $(\mathrm{P}<0.05)$ crude fiber intake compared to the other treatments (Table 3).

The use of soybean pod at the levels of 15\% (T2) and $30 \%$ (T3) in the complete feed significantly increased $(\mathrm{P}<0.05)$ the digestibilities of dry matter, crude protein, and nitrogen free-extract compared to the native grass (T0) or concentrate (T1) based ration. 
Furthermore, the digestibilities of ether extract were higher $(\mathrm{P}<0.05)$ in the cattle fed with concentrate ration (T1), complete ration containing soybean pod $15 \%$ (T2) and $30 \%$ (T3) compared to those fed with native-grass based ration (T0). However, crude fiber digestibilities were similar among treatments (Table 3 ).

\section{Microbial Population, Fermentation Characteristics, and Methane Estimation}

Protozoa population, bacterial population, ammonia concentration, total VFA, acetate/propionate ratio, and methane estimation were similar among treatments. In contrast, the use of concentrate ration or complete ration containing soybean pod significantly increased $(\mathrm{P}<0.05)$ butyrate proportion compared to the native grass based ration. The use of concentrate ration resulted the highest propionate proportion (Table 4).

\section{Nitrogen Retention}

The use of soybean pod at the level of $15 \%$ in the complete ration (T2) significantly increased $(\mathrm{P}<0.05) \mathrm{N}$ intake, $\mathrm{N}$ Digestibiliy, $\mathrm{N}$ retention, $\mathrm{N}$ excretion in the urine, and $\mathrm{N}$ retention compared to the native grass based ration (T0). In contrast, there were slightly decreases in $\mathrm{N}$ intake, $\mathrm{N}$ digestibility, and $\mathrm{N}$ retention with the use of soybean pod at the hihger level (30\%) compared to the lower level (15\%). The nitrogen contents of feces were similar among treatments. However, the use of soybean pod still have better $\mathrm{N}$ retentions compared to the ration with $100 \%$ grass or concentrate-based ration (Table 5).

Table 3. Nutrient intake and digestibility of madura cattle fed complete ration containing soybean by-product and soybean pod

\begin{tabular}{lrrrr}
\hline \multicolumn{1}{c}{ Variables } & \multicolumn{2}{c}{ Treatments } & \multicolumn{1}{c}{ T2 } \\
\cline { 2 - 5 } & \multicolumn{1}{c}{ T0 } & T1 & & \\
\hline Nutrient intake (kg/h/d) & & & & \\
Dry matter (DM) & $5.60 \pm 0.44^{\mathrm{bc}}$ & $4.90 \pm 0.02^{\mathrm{c}}$ & $1.90 \pm 0.79^{\mathrm{a}}$ & $6.60 \pm 0.58^{\mathrm{ab}}$ \\
Crude protein (CP) & $0.60 \pm 0.04^{\mathrm{b}}$ & $0.70 \pm 0.03^{\mathrm{b}}$ & $0.13^{\mathrm{a}}$ & $0.80 \pm 0.69^{\mathrm{b}}$ \\
Ether extract (EE) & $64.00 \pm 5.10^{\mathrm{c}}$ & $82.20 \pm 3.60^{\mathrm{bc}}$ & $105.80 \pm 10.50^{\mathrm{ab}}$ & $112.00 \pm 9.80^{\mathrm{a}}$ \\
Crude fiber (CF) & $1.80 \pm 0.14^{\mathrm{a}}$ & $0.90 \pm 0.08^{\mathrm{c}}$ & $1.20 \pm 0.12^{\mathrm{b}}$ & $1.20 \pm 0.11^{\mathrm{b}}$ \\
Nitrogen free extract (NFE) & $2.50 \pm 0.20^{\mathrm{b}}$ & $2.80 \pm 0.09^{\mathrm{b}}$ & $4.70 \pm 0.47^{\mathrm{a}}$ & $3.90 \pm 0.34^{\mathrm{a}}$ \\
Nutrient digestibility (\%) & & & & \\
Dry matter (DM) & $64.60 \pm 2.90^{\mathrm{c}}$ & $77.60 \pm 0.10^{\mathrm{b}}$ & $83.00 \pm 3.50^{\mathrm{a}}$ & $83.60 \pm 2.80^{\mathrm{a}}$ \\
Crude protein (CP) & $74.50 \pm 1.60^{\mathrm{c}}$ & $84.70 \pm 1.30^{\mathrm{b}}$ & $89.40 \pm 1.10^{\mathrm{a}}$ & $87.00 \pm 1.50^{\mathrm{ab}}$ \\
Ether extract (EE) & $61.00 \pm 15.50^{\mathrm{b}}$ & $88.60 \pm 0.50^{\mathrm{a}}$ & $86.00 \pm 5.50^{\mathrm{a}}$ & $88.80 \pm 1.30^{\mathrm{a}}$ \\
Crude fiber (CF) & $70.90 \pm 1.30$ & $71.60 \pm 5.50$ & $70.00 \pm 7.40$ & $74.30 \pm 6.70$ \\
Nitrogen free extract (NFE) & $60.00 \pm 5.10^{\mathrm{c}}$ & $78.40 \pm 4.50^{\mathrm{b}}$ & $86.80 \pm 2.50^{\mathrm{a}}$ & $88.10 \pm 2.00^{\mathrm{a}}$ \\
\hline
\end{tabular}

Note: Means in the same row with different superscript differ significantly $(\mathrm{P}<0.05) . \mathrm{T} 0=100 \%$ native grass $)$, $\mathrm{T} 2=\mathrm{concentrate}:$ grass $(60: 40)$, T3= complete feed containing $15 \%$ soybean pods, T4= complete feed containing $30 \%$ soybean pods. ${ }^{*}$ by calculation.

Table 4. Concentration of $\mathrm{NH}_{3}$, volatile fatty acid, bacteria and protozoa numbers of Madura cattle fed with complete ration containing soybean by-product and soybean pod

\begin{tabular}{lrrrr}
\hline \multirow{2}{*}{ Variabel } & \multicolumn{1}{c}{ Treatments } \\
\cline { 2 - 5 } & \multicolumn{1}{c}{ T0 } & \multicolumn{1}{c}{ T2 } & T3 \\
\hline Protozoa $(\log 10 / \mathrm{mL})$ & $6.60 \pm 0.80$ & $6.10 \pm 0.60$ & $6.20 \pm 0.30$ & $6.50 \pm 0.40$ \\
Bacterial population $(\log 10 \mathrm{CFU} / \mathrm{mL})$ & $9.80 \pm 0.00$ & $9.80 \pm 0.20$ & $9.80 \pm 0.10$ & $9.90 \pm 0.20$ \\
NH3 (mM) & $3.10 \pm 1.80$ & $3.50 \pm 0.50$ & $7.50 \pm 4.01$ & $6.00 \pm 1.90$ \\
Total VFA (mM) & $54.21 \pm 4.31$ & $72.80 \pm 15.99$ & $72.59 \pm 9.66$ & $52.36 \pm 6.49$ \\
Proportional VFA (mM/100mM) & & & \\
$\quad$ Acetate (C2) & $72.12 \pm 0.87$ & $65.37 \pm 2.77$ & $67.91 \pm 3.66$ & $68.63 \pm 0.70$ \\
$\quad$ Propionate (C3) & $16.18 \pm 0.18$ & $17.73 \pm 4.49$ & $13.91 \pm 2.21$ & $13.34 \pm 1.34$ \\
$\quad$ Butyrate (C4) & $9.70 \pm 0.57 \mathrm{~b}$ & $15.42 \pm 1.53^{\mathrm{a}}$ & $15.43 \pm 2.35^{\mathrm{a}}$ & $15.42 \pm 1.03^{\mathrm{a}}$ \\
$\quad$ Valerate (C5) & $2.01 \pm 0.12$ & $1.48 \pm 0.19$ & $2.75 \pm 0.72$ & $2.62 \pm 0.42$ \\
$\quad$ C2/C3 ratio & $4.46 \pm 0.10$ & $3.83 \pm 1.13$ & $4.99 \pm 1.03$ & $5.18 \pm 0.54$ \\
Methane estimation & $17.29 \pm 1.49$ & $22.11 \pm 2.66$ & $23.81 \pm 2.38$ & $17.46 \pm 2.03$ \\
\hline
\end{tabular}

Note: ${ }^{*}$ Moss et al. (2000). T0= 100\% native grass), T2= concentrate : grass $(60: 40), \mathrm{T} 3=$ complete feed containing $15 \%$ soybean pods, $\mathrm{T} 4=\mathrm{complete}$ feed containing $30 \%$ soybean pods. ${ }^{*}$ by calculation. 


\section{Feed Efficiency and Performance of Madura Cattle}

Madura beef cattle fed complete feeds containing soybean by-product and soybean pod at the level of $15 \%$ or $30 \%$ significantly increased feed intake compared to those fed concentrate and native-grass based ration and significantly increased feed effiency, final body weight, and average daily gain compared to those fed only native grass (Table 6).

\section{DISCUSSION}

The increased dry mater intake in the Madura beef cattle fed complete ration containing soybean pod at the level of $15 \%$ indicates that soybean pod has a good palatability at this level. In contrast, the addition soybean pod at the level of $30 \%$ slightly decreased dry matter and crude protein intakes compared to the lower level of soybean pod supplementation (15\%). The decrease might be due to the increased crude fiber content of the complete feed (Table 2). A previous meta analysis showed that the content of crude fiber influenced the dry matter intake of ruminant cattle (Riaz et al., 2014). In this study it was also proved that the Madura beef cattle fed native grass containing the highest crude fiber had the lowest dry matter intake.

The increased nutrient digestibility in cattle fed complete rations supplemented with soybean pod was caused by the improved feed degradation by the rumen microbes. Despite the lignin content of soybean pod is similar to that of native grass $(12 \%)$, the digestibilities of $\mathrm{DM}, \mathrm{CP}$, and NFE of complete feed containing soybean pod were not altered. Furthermore, the use of native grass and concentrate-based rations having higher lignin contents (Table 2) decreased dry matter digestibilities. Lignin could not be digested by the rumen bacteria. Lignin becomes a physical barrier for the microbial enzymes to reach the polysaccarides of the feed (Moore \& Jung, 2001). Mahes \& Mohini (2013) sugested that the crop residue was lignocellulosic because of a high content of cellulose bounded with lignin therefore rumen microbes could not break this bond efficiently. Furthermore, the crude fiber digestibilities were almost similar among treatments and were higher than those reported by Bain et al. (2016) that the crude fiber digestibility in Bali Cattle fed ration containing $40 \%$ native grass was around $49 \%$.

Population of protozoa was not affected by the supplementation of soybean pod in the ration since there was no antiprotozoa compound such as saponin that was reported in the soybean pod. Shimoyada et al. (1990) reported that saponin level in the pod shell was around $0.01 \%-0.25 \%$. This level is too low to be able to inhibit the growth of protozoa. In the rumen, protozoa have roles in the degradation of feed materials. The use of complete feed containing soybean pod up to $30 \%$ also did not alter the growth of rumen bacteria. This result revealed that there was no secondary compound in the soybean pod which may harm the rumen bacteria. Rumen microbes (protozoa and bacteria) have important roles in the degradation and fermentation of feed (Wang \& McAllister, 2002).

The use of complete ration containing soybean pod up to $30 \%$ or concentrate-based ration resulted the similar production of ammonia compared to the nativegrass based ration. Although the digestibility of crude

Table 5. Nitrogen retention of Madura cattle fed complete feed containing soybean by-product and soybean pod

\begin{tabular}{|c|c|c|c|c|}
\hline \multirow{2}{*}{ Variables } & \multicolumn{4}{|c|}{ Treatments } \\
\hline & T0 & T1 & $\mathrm{T} 2$ & T3 \\
\hline N Intake (g) & $88.0 \pm 6.9^{\mathrm{b}}$ & $105.4 \pm 4.0^{\mathrm{b}}$ & $207.5 \pm 20.7^{a}$ & $126.7 \pm 11.1^{\mathrm{b}}$ \\
\hline N Feces (g) & $22.0 \pm 0.4$ & $16.1 \pm 2.1$ & $22.2 \pm 4.0$ & $16.6 \pm 3.2$ \\
\hline N Digestible (g) & $66.0 \pm 6.6^{c}$ & $89.3 \pm 2.0^{\mathrm{bc}}$ & $185.3 \pm 17.1^{\mathrm{a}}$ & $110.1 \pm 8.2^{\mathrm{b}}$ \\
\hline N Urin $(g)$ & $28.9 \pm 0.8^{b}$ & $54.6 \pm 2.7^{a}$ & $38.1 \pm 4.1^{\mathrm{ab}}$ & $46.1 \pm 10.4^{\mathrm{ab}}$ \\
\hline N Retention (g) & $37.1 \pm 7.4^{\mathrm{b}}$ & $34.7 \pm 0.7 \mathrm{~b}$ & $147.2 \pm 21.0^{\mathrm{a}}$ & $64.0 \pm 12.3^{b}$ \\
\hline N Retention from N intake (\%) & $41.9 \pm 5.1^{\mathrm{bc}}$ & $32.9 \pm 1.9^{c}$ & $70.7 \pm 3.5^{\mathrm{a}}$ & $50.5 \pm 8.6^{\mathrm{b}}$ \\
\hline N Retention from N Digestible (\%) & $55.9 \pm 5.7^{b}$ & $38.8 \pm 1.6^{\mathrm{b}}$ & $79.2 \pm 4.3^{\mathrm{a}}$ & $58.0 \pm 9.4^{\mathrm{b}}$ \\
\hline
\end{tabular}

Note: Means in the same row with different superscript differ significantly $(\mathrm{P}<0.05)$. T0=100\% native grass), T2= concentrate : grass $(60: 40)$, T3= complete feed containing $15 \%$ soybean pods, T4= complete feed containing $30 \%$ soybean pods. ${ }^{*}$ by calculation.

Table 6. Feed effciency and performance of Madura cattle fed complete feed containing soybean by-product and soybean pod

\begin{tabular}{lrrrr}
\hline \multirow{2}{*}{\multicolumn{1}{c}{ Variables }} & \multicolumn{3}{c}{ Treatments } \\
\cline { 2 - 5 } & \multicolumn{1}{c}{ T0 } & T1 & T2 & T3 \\
\hline Initial body weight $(\mathrm{kg})$ & $177.00 \pm 28.62$ & $171.00 \pm 1.41$ & $176.33 \pm 15.14$ & $176.67 \pm 16.44$ \\
Final body weight $(\mathrm{kg})$ & $201.67 \pm 43.13^{\mathrm{b}}$ & $231.50 \pm 16.26^{\mathrm{a}}$ & $237.00 \pm 27.87^{\mathrm{a}}$ & $228.00 \pm 16.52^{\mathrm{a}}$ \\
DM feed intake $(\mathrm{kg})$ & $4.79 \pm 1.49^{\mathrm{b}}$ & $6.23 \pm 0.01^{\mathrm{a}}$ & $7.00 \pm 0.57^{\mathrm{a}}$ & $6.80 \pm 0.31^{\mathrm{a}}$ \\
Feed efficiency & $5.36 \pm 2.40^{\mathrm{c}}$ & $11.03 \pm 2.68^{\mathrm{a}}$ & $9.76 \pm 1.32^{\mathrm{ab}}$ & $8.62 \pm 1.42^{\mathrm{bc}}$ \\
\hline
\end{tabular}

Note: Means in the same row with different superscript differ significantly $(\mathrm{P}<0.05)$. T0=100\% native grass), T2= concentrate : grass $(60: 40)$, $\mathrm{T} 3=\mathrm{com}-$ plete feed containing $15 \%$ soybean pods, T4= complete feed containing $30 \%$ soybean pods. ${ }^{*}$ by calculation. 
protein significantly improved with the use of complete ration containing soybean pod or concentrate-based ration (Table 3), ammonia productions in the rumen were similar for all treatments. This result might be due to the use of compounds produced from digestion of crude protein by the experimental cattle as was reflected by the increased $\mathrm{N}$ retention in cattle fed complete rations containing soybean pod and soybean by-product (Table 4). However, the ammonia concentrations in this study were lower than those reported by Suharti et al. (2011) that the use of forage (native gras) up to $90 \%$ in the in vitro fermentation produced rumen ammonia around $12.3 \mathrm{mM}$. Furthermore, Suharti et al. (2015) also reported that the use of high forage feed in beef cattle produced ammonia concentrations that were similar with this study (around $7.47 \mathrm{mM}$ ).

The similar concentrations of total VFA for all treatments indicates that the use of complete rations containing soybean by-product and soybean pod or concentrate-based ration could not increase the efficiency of fermentation. This result did not in line with the dry matter digestibility which increased with the use of complete rations containing soybean by-product and soybean pod or concentrate based ration. Previous study showed that there were positive correlations between dry matter intakes and digestibilities with total VFA concentrations (Wanapat et al., 2013). Molar concentrations of VFA such as acetate, propionate, valerate, ratio of acetate/propionate, and methane estimation were similar among treatments showing that the efficiency of nutrient convertion to VFA products was not changed. Previous study showed that many factors could influence total VFA concentration and molar proportion of VFA i.e., dry matter intake, diet composition, truly digested in the rumen, and the utilization rate of substrate by the rumen microorganism (Bannink et al., 2006).

In contrast, butyrate proportion increased with the use of complete ration containing soybean by-product and soybean pod as well as concentrate-based ration. The increase in butyrate proportion might be due to the increased level of highly fermentable diets such as starch in those rations containing higher NFE than native-grass based ration (Table 2). Short-chain fatty acid (SCFA), particularly butyrate, will linearly increase with the increasing level of highly fermentable carbohydrate. Moreover, the intraepithelial metabolism of SCFA, particularly butyrate, has a role in maintaining the gradient concentration between the cytosol and the lumen, thereby facilitating the absorption (Penner et al., 2014).

The increasing level of $\mathrm{N}$ intake with the use of complete ration containing soybean by-product and soybean pod at the level of $15 \%$ linearly increased dry matter and crude protein intakes compared to the other treatments. Furthermore, with the same level of $\mathrm{N}$ in feces and a lower level of $\mathrm{N}$ in urin resulted in the increased $\mathrm{N}$ digestibility and $\mathrm{N}$ retention in the cattle fed with complete rations containing soybean by-product and soybean pod. The improved nitrogen retention indicates the improved level of protein utilization by the experimental cattle and reduced level of $\mathrm{N}$ excreted in the urin or feces. The reduced excretion of $\mathrm{N}$ from live- stock will have positive effects on the environment (Ma et al., 2014). The proportion of excreted $\mathrm{N}$ into feces and urine mostly depend on diet, and the level $\mathrm{N}$ excretion in the urine can reach up to $75 \%$ when high-protein and high-concentrate diets are fed (Hristov et al., 2011). The use of soybean by-product such as soybean meal and tofu waste in the complete ration could supply good proteins that have high utilizations in beef cattle.

The increased feed intake in cattle fed complete ration containing soybean pod up to $30 \%$ reveals that soybean pod has a high palatibility as a feed stuff in beef cattle despite the dry texture. The improved feed intake and body weight gain could increase feed utilization in Madura beef cattle fed a complete ration containing soybean pod or concentrate ration. This result indicates that a complete ration containing soybean pod can improve the performans of Madura beef cattle as good as a concentrate ration. Further more, carcass and meat characteristics of Madura cattle fed soybean by-products based ration were similar to those fed $100 \%$ native grass (Fuah et al., 2016). Soybean pod is an agricultural by-product which has a great potential as an alternative feed resource to substitute native grass for beef cattle.

\section{CONCLUSION}

The use of concentrate ration or complete feed containing soybean pod increased butyrate proportion and could improve $\mathrm{N}$ intake, $\mathrm{N}$ digestible, $\mathrm{N}$ retention, and $\mathrm{N}$ urin compared to the native grass based ration (T0) treatment. Therefore, soybean pod has a potential to be used as fiber source in beef cattle ration to substitute native grass.

\section{ACKNOWLEDGEMENT}

The authors would like to thank Ministry of Research, Technology and Higher Education for funding this research through the International Research Collaboration and Scientific Publication Grant No. 083/ SP2H/PL/Dit.Litabmas/II/2015 date February 5, 2015.

\section{REFERENCES}

Bain, A., D. A. Astuti, S. Suharti, C. Arman, \& K. G. Wiryawan. 2016. Performance, nutrient digestibility, and meat quality of bali cattle fed a ration supplemented with soybean oil calcium soap and cashew fruit flour. Med. Pet. 39:180-188. https://doi.org/10.5398/medpet.2016.39.3.180

BPS-Statistic Indonesia. 2015. Production of Soybeans by Province (ton), 1993-2015. https://www.bps.go.id

Conway, E. J. 1962 Ammonia. General Method. Microdiffusion Analysis and Volumetric Error. Crosby Lockwood and Son Ltd., London, UK., Page 98-100.

Bannink, A., J. Kogut, J. Dijkstra, J. France, E. Kebreab, A. M. Van Vuuren, \& S. Tamming. 2006. Estimation of the stoichiometry of volatile fatty acid production in the rumen of lactating cows. J. Theor. Biol. 238:36-51. https://doi. org/10.1016/j.jtbi.2005.05.026

Foster J. L., A. T. Adesogan, J. N. Carter, A. R. Blount, R. O. Myer, \& S. C. Phatak. 2014. Intake, digestibility, and nitrogen retention by sheep supplemented with warm-season legume haylages or soybean meal. J. Anim. Sci. 87:28992905. https://doi.org/10.2527/jas.2009-1828 
Fuah, A. M., R. Priyanto, S. Suharti, K. G. Wiryawan, \& M. Ismail. 2016. Productivity and meat quality of local cattle fed soybean by-product. Pakistan Journal of Nutrition. 15:364-369. https://doi.org/10.3923/pjn.2016.364.369

Hristov, A. N., M. Hanigan, A. Cole, R. Todd, T. A. McAllister, P. M. Ndegwa, \& A. Rotz. 2011. Review: Ammonia emissions from dairy farms and beef feedlots. Can. J. Anim. Sci. 91:1-35. https://doi.org/10.4141/CJAS10034

Kearl, L. C. 1982. Nutrient Requirements of Ruminants in Developing Countries. All Graduate Theses and Dissertations. Paper 4183. Utah State University.

Moore, K. J. \& H. G. Jung. 2001. Lignin and fiber digestion. J. Range Manage. 54: 420-430. https://doi. org/10.2307/4003113

Kennedy, C. L. Baker, S. Dhakal \& A. Ramaswami. 2012. Sustainable urban systems: an integrated approach. J. Ind. Ecol. 16: 775-779. https://doi. org/10.1111/j.1530-9290.2012.00564.x

Ma, T., K. Deng, Y. Tu, C. Jiang, N. Zhang, Y. Li, B. Si, C. Lou \& Q. Diao. 2014. Effect of dietary concentrate:forage ratios and undegraded dietary protein on nitrogen balance and urinary excretion of purine derivatives in dorper $x$ thintailed Han crossbred lambs. Asian Australas. J. Anim. Sci. 27: 161-168. https://doi.org/10.5713/ajas.2013.13338

Mahesh, M. S. \& M. Mohoni. 2013. Biological treatment of crop residues for ruminant feeding: A review. African J. Biotech. 12: 4221-4231. https://doi.org/10.5897/AJB2012.2940

Moss, A. R., J. P. Jouany, \& J. Newbold. 2000. Methane production by ruminants: Its contribution to global warming. Annal. Zootechnology. 49: 231-253. http://dx.doi. org/10.1051/ animres:2000119

Mukherjee, R., R. Chakraborty, \& A. Dutta. 2016. Role of fermentation in improving nutritional quality of soybean meal - a review. Asian Australas. J. Anim. Sci. 29: 15231529. https://doi.org/10.5713/ajas.15.0627
Ogimoto, K. \& S. Imai. 1981. Atlas of Rumen Microbiology. Japan Scientific Societes, Tokyo.

Penner, G. B., M. A. Steele, J. R. Aschenbach, \& B. W. McBride. 2011. Ruminant Nutrition Symposium: Molecular adaptation of ruminal epithelia to highly fermentable diets. J. Anim. Sci. 89:1108-1119. https://doi.org/10.2527/ jas.2010-3378

Riaz, M. Q., K. H. Sudekum, M. Claus, \& A. Jayanegara. 2014 Voluntary feed intake and digestibility of four domestic ruminant species as influenced by dietary constituents: A meta-analysis. Livestock Sci. 162:76-85. https://doi. org/10.1016/j.livsci.2014.01.009

Shimoyada, M., S. Kudo, K. Okubo, F. Yamauchi \& K. Harada. 1990. Distributions of saponin constituents in some varieties of soybean plant. Agric. Bioi. Chem. 54: 77-81.

Suharti, S., D. A. Astuti, E. Wina, \& T. Toharmat. 2011. Rumen microbial population in the in vitro fermentation of different ratios of forage and concentrate in the presence of whole lerak (Sapindus rarak) Fruit Extract. Asian-Australas. J. Anim. Sci. 24: 1086-1091. https://doi.org/10.5713/ ajas.2011.10409

Suharti, S., D. A. Astuti, E. Wina, \& T. Toharmat. 2015 Digestibility, fermentation characteristic, protein microbial synthesis and growth performance of beef cattle fed high forage ration with lerak extract supplementation. Pakistan Journal of Nutrition 14: 885-891. https://doi.org/10.3923/ pjn.2015.885.891

Wanapat, M., N. Anantasook, P. Rowlinson, R. Pilajun \& P. Gunun. 2013. Effect of carbohydrate sources and levels of cotton seed meal in concentrate on feed intake, nutrient digestibility, rumen fermentation and microbial protein synthesis in young dairy bulls. Asian-Australas. J. Anim. Sci. 26: 529-536. DOI: https://doi.org/10.5713/ajas.2012.12607

Wang, Y. \& T. A. McAllister. 2002. Rumen microbes, enzymes and feed digestion-a review. Asian-Aust. J. Anim. Sci. 15: 1659-1676. 